\title{
Successful pregnancy outcome in a case of Swyer Syndrome with hypertension and morbid obesity
}

\author{
Aradhana Kalra*, Purnima K. Nadkarni, Pooja P. Singh, Aditi A. Nadkarni
}

Department of Reproductive Medicine, Nadkarni's 21st century Hospital and test tube baby centre, Surat, Gujarat, India

Received: 22 April 2016

Accepted: 16 May 2016

\section{*Correspondence:}

Dr. Aradhana Kalra,

E-mail: draradhanakalra@gmail.com

Copyright: ( $\odot$ the author(s), publisher and licensee Medip Academy. This is an open-access article distributed under the terms of the Creative Commons Attribution Non-Commercial License, which permits unrestricted non-commercial use, distribution, and reproduction in any medium, provided the original work is properly cited.

\begin{abstract}
To report a case of Swyer syndrome with hypertension and morbid obesity with successful pregnancy and live birth after assisted reproductive technology. 27 year old morbidly obese female with essential hypertension who had been on HRT for 10 years with well-developed secondary sexual characters with primary infertility. After adequate development of the uterus and the endometrial preparation, Patients with Swyer syndrome conceive with oocyte donation and ICSI. Caesarean section rate is high due to multiple pregnancies and other obstetric complications. Early detection of these cases would help in timely development of their secondary sexual characters and restoration of menses and gonadectomy for prevention of malignancy as its propensity is high. Multidisciplinary approach is required including counseling and management of long term health problems. Pregnancy is feasible but caesarean rate is high.
\end{abstract}

Keywords: Gonadal dysgenesis, Multidisciplinary care, Gonadectomy, Oocyte donation

\section{INTRODUCTION}

The term Swyer syndrome was coined by Gim Swyer in 1955 where he described two cases of sex reversal that differed from the known forms of what was then termed 'male pseudo hermaphroditism'. The two women had a 46XY karyotype and had primary amenorrhoea, tall stature, female external genitalia (although one had an enlarged clitoris) and normal albeit hypoestrogenised vagina and cervix. ${ }^{1}$ The condition was later linked to dysgenetic gonads and is also known as pure gonadal dysgenesis, a form of 46XY Disorder of Sexual Development. It is an unusual condition with an incidence of 1 in 80,000 and is characterized by the presence of an unambiguously female phenotype and mullerian structures in the presence of a "Y" line. ${ }^{2} 10$ to $20 \%$ of women with the syndrome have a deletion in the DNA-binding region of the SRY gene while in the remaining $80-90 \%$ of cases, the SRY gene is normal and mutations in other testis determining factors are probably implicated. ${ }^{3}$ Early diagnosis is important, as gonadal neoplasm is common in these patients.

\section{METHODS}

A 27 year old lady presented to our centre with primary Infertility. She had visited a clinic at the age of 17 years with primary amenorrhea and no development of the secondary sexual characters. Since then she was put on Hormone replacement therapy. So when she visited our clinic she had regular periods and well developed secondary sexual characters. Her family history was unremarkable. On examination she was a tall female with morbid obesity $5 \mathrm{ft} 10$ inches high, weighing $129 \mathrm{~kg}$, BMI: 40.8. Arm span was $180 \mathrm{~cm}$. Breast and pubic hair tanners 5 and external genitilia of a normal female. Internal examination revealed a small uterus with nonpalpable ovaries. Her blood pressure was 190/100mm Hg and she was not a diagnosed case of hypertension.

Hormonal evaluation revealed FSH: 30 IU/L, LH: 7.16 IU/L, E2: $36 \mathrm{pg} / \mathrm{ml}$, Growth hormone: $0.064 \mathrm{ng} / \mathrm{ml}$, TSH: 2microIU/ml and prolactin: $7 \mathrm{ng} / \mathrm{ml}$. Her Blood sugar (fasting and post prandial), kidney function tests, lipid 
profile, Serum cortisol were normal. Anti-phospholipid antibody screen was negative. Echocardiography and renal Doppler were also normal. Karyotype 46XY. Ultrasonography revealed small uterus $4.7 \times 2.0 \times 3.1 \mathrm{~cm}$, ET: 5mm, with small gonads Cervix: normal. MRI revealed streak gonads $10 \times 9 \mathrm{~mm}$ and $10 \times 11 \mathrm{~mm}$ along the broad ligaments. Our case was diagnosed as $46 \mathrm{XY}$ Disorder of sexual Development (DSD) namely pure gonadal dysgenesis or Swyer syndrome. On laparoscopy there were B/L streak gonads and gonadectomy was done as the propensity of malignancy is high. Patient was advised life style modifications for weight reduction, salt restriction and anti-hypertensives. Meanwhile the patient was on regular follow up and hormone replacement therapy (17b estradiol gel and progesterone) was continued. After 1 year when she had a controlled blood pressure and had lost $30 \mathrm{kgs}$ we took her up for oocyte donation and ICSI with husband's sperm. First cycle failed where 3 day 3 embryos were transferred. After two months in second attempt two day 5 expanded blastocyst transfer was done. Serum b HCG on day 16 after transfer was 813 . Her first sonography revealed single live intra uterine pregnancy. Luteal support was with Estradiol valerate (valest) $2 \mathrm{mg}, 17 \mathrm{~B}$ estradiol gel and micronized progesterone $800 \mathrm{mg}$. In addition to luteal support and folate supplementation, Salicylic acid was given empirically. Patient was also heparinized after transfer. Her first trimester was uneventful. Uterine artery Doppler at 16 weeks revealed a dicrotic notch and she had an episode of bleeding per vagina at the same time. Salicylic acid and LMWH was stopped and restarted after 2 weeks. Patient developed super imposed pre eclampsia at 28 weeks and pregnancy was terminated at 34 weeks by LSCS due to severe pre eclampsia and a healthy girl child weighing $2.1 \mathrm{Kg}$ was born.

Table 1: Case reports of pregnancies in patients with Swyer syndrome.

\begin{tabular}{|c|c|c|c|c|c|}
\hline Study & $\begin{array}{l}\text { No of } \\
\text { patients }\end{array}$ & $\begin{array}{l}\text { Single /multiple } \\
\text { pregnancy }\end{array}$ & $\begin{array}{l}\text { Pregnancy } \\
\text { complications }\end{array}$ & $\begin{array}{l}\text { Mode of } \\
\text { delivery }\end{array}$ & Indication for CS \\
\hline Sauer et $\mathrm{al}^{5}$ & 1 & twin & preeclampsia & $\mathrm{CS}$ & Severe preeclampsia \\
\hline Cornet et $\mathrm{al}^{6}$ & 3 & single & No & $\mathrm{CS}$ & Android pelvis \\
\hline 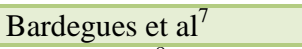 & 1 & triplet & Nil & CS & PTL, PPROM \\
\hline 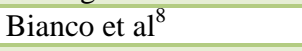 & 1 & single & Nil & Not known & \\
\hline Kan et $\mathrm{al}^{9}$ & 1 & $\begin{array}{l}\text { 1st single } \\
2 \mathrm{nt} \text { twin }\end{array}$ & Gestational HTN & $\mathrm{CS}$ & $\begin{array}{l}\text { Failed induction } \\
\text { Previous CS with twin }\end{array}$ \\
\hline Dirnfield et al $^{10}$ & 2 & Single and twin & No & $\mathrm{CS}$ & \\
\hline Selvaraj et al ${ }^{11}$ & 1 & Single & No & $\mathrm{CS}$ & Failed induction \\
\hline Chen et al ${ }^{12}$ & 1 & Twin & No & $\mathrm{CS}$ & Malpresentation of twin \\
\hline Ko et $\mathrm{al}^{13}$ & 1 & triplet & $\begin{array}{l}1 \text { hydatidiform } \\
\text { mole and } \\
\text { preeclampsia }\end{array}$ & $\mathrm{CS}$ & Preeclampsia \\
\hline Plante and Fritz ${ }^{14}$ & 1 & Single & No & $\mathrm{CS}$ & $\begin{array}{l}\text { Occipito post position } \\
\text { with arrest of head } \\
\text { descent, Bwt } 3.617\end{array}$ \\
\hline Siddique et $\mathrm{al}^{15}$ & 1 & Single & No & Vaginal & \\
\hline Tulic et $\mathrm{al}^{16}$ & 1 & Single & $\begin{array}{l}\text { Reduced } \\
\text { amniotic fluid }\end{array}$ & $\mathrm{CS}$ & $\begin{array}{l}\text { Breech with } \\
\text { oligohydramnios }\end{array}$ \\
\hline Michala et $\mathrm{al}^{4}$ & 3 & single & $\begin{array}{l}\text { 1-Nil } \\
\text { 2-Nil } \\
\text { 3-Preeclampsia }\end{array}$ & $\begin{array}{l}1-\mathrm{VD} \\
2-\mathrm{VD} \\
3-\mathrm{CS}\end{array}$ & 3-Preeclampsia \\
\hline George Creatsas et al ${ }^{17}$ & 1 & Single & $\begin{array}{l}\text { Chronic } \\
\text { Hypertension }\end{array}$ & $\mathrm{CS}$ & IUGR with fetal distress \\
\hline Azamsadat et al ${ }^{18}$ & 1 & Single & Preeclampsia & CS & Preeclampsia \\
\hline
\end{tabular}

\section{DISCUSSION}

Swyer syndrome is a sex-reversal disorder resulting from embryonic testicular regression sequences. Clinical diagnosis is difficult and usually made at later ages and as a result of clinical presentations such as primary amenorrhea and/or delayed development of secondary sexual characters. However, early diagnosis is important because of the risk of gonadal malignancy, the early institution of estrogen therapy for induction of puberty and to allow for adequate hormone replacement to improve bone mineral density. ${ }^{4}$ Our patient was given HRT for primary amenorrhea but she was not evaluated further until she visited our centre for infertility when she was diagnosed and gonadectomy done. The delay from the primary visit being 10 years.

The patients with Swyers are considered sterile. However pregnancy is possible with allogenic oocytes after adequate development of the uterus and proper priming 
of the endometrium. The first pregnancy and delivery by ovum donation was reported in 1984. After extensive literature search we found 15 papers from 1989 to 2012 of 20 women with swyers with a successful pregnancy outcome. Out of which only 1 patient had pre-existing hypertension (Creatsas $\mathrm{G}$ et al) as in our patient (Table 1). As our patient had hypertension and was morbidly obese, it was important to use the lowest possible dose of hormones to get the desired effect. Hypertension per se is not a contraindication for HRT but obesity and HRT may increase the risk of venous thromboembolism. 17b estradiol is preferred over ethinyl estradiol in such patients. ${ }^{19}$ We gave the patient $17 \mathrm{~b}$ estradiol gel and nor ethisterone during the interval period of 1 year before ICSI. The patient was managed in liaison with the endocrinologist and physician. Post transfer luteal support was given with $2 \mathrm{mg}$ ethinyl estradiol and $17 \mathrm{~b}$ estradiol gel twice daily (normally for OD cycles we give $6 \mathrm{mg}$ ethinyl estradiol) up to 12 weeks and we also gave her Low molecular weight heparin.

The use of allogenic oocytes and the endometrial response to exogenous hormones has enabled these patients to successfully achieve pregnancy. However due to the increased incidence of multiple pregnancies, preterm labor, premature rupture of membranes, hypertension the caesarean rate in the number of cases reported is high. In the cases reported by Sauer at al, Bardeguez et al, Chen et al, Ko et al, Plante et al, Tulic et al, Michala et al, Creatsas et al and Azamsadat et al Cesarean section was performed for various obstetric complications before spontaneous/induced labor as in our case. $^{4,5,7,12-14,16-18}$ In the case report by Cornet et al Elective cesarean was done for android pelvis. ${ }^{6}$ Only Kan et al and Selvaraj et al reported failed induction while Siddique et al and Michala et al reported successful vaginal delivery in three cases. ${ }^{4,9,11,15}$ The hypoplastic uterus responds well to hormonal therapy and it may have anatomical ability to permit normal dilatation and labor however more reports with vaginal delivery would be required to support that.

We have documented a rare case of Swyer syndrome with primary hypertension and morbid obesity with successful pregnancy and delivery of a healthy baby. We adopted a multidisciplinary care approach for her along with counselling both psychological and genetic.

Funding: No funding sources

Conflict of interest: None declared

Ethical approval: Not required

\section{REFERENCES}

1. Swyer GI. Male pseudo hermaphroditism: a hitherto undescribed form. Br Med J. 1955;2:709-12.

2. Lee AC, Fong CM. Ovarian choriocarcinoma as the first manifestation of 46, XY pure gonadal dysgenesis. J Pediatr Hematol Oncol. 2011;33:29-31.
3. Jager RJ, Anvret M, Hall K, Scherer G. A human XY female with a frameshift mutation in the candidate testis-determining gene SRY. Nature. 1990;348:4524.

4. Michala L, Goswami D, Creighton SM, Conway GS. Swyer syndrome: presentation and outcomes. BJOG. 2008;115:737-41.

5. Sauer MV, Lobo RA, Paulson RJ. Successful twin pregnancy after embryo donation to a patient with XY gonadal dysgenesis. Am J Obstet Gynecol. 1989;161:380-1.

6. Cornet D, Alvarez S, Antoine JM, Tibi C, Mandelbaum J, Plachot M, et al. Pregnancies following ovum donation in gonadal dysgenesis. Hum Reprod. 1990;5:291-3.

7. Bardeguez AD, De Ziegler D, Weiss G. Multifetal pregnancy in a gonadal dysgenesis mosaic. Obstet Gynecol. 1990;76:502-4.

8. Bianco S, Agrifoglio V, Mannino F, Cefal u E,Cittadini E. Successful pregnancy in a pure gonadal dysgenesis with karyotype 46, XY patient (Swyer's syndrome) following oocyte donation and hormonal treatment. Acta Eur Fertil. 1992;23:37-8.

9. Kan AK, Abdalla HI, Oskarsson T. Two successful pregnancies in a 46, XY patient. Hum Reprod. 1997; 12:1434-5.

10. Dirnfeld M, Bider D, Abramovicia H, Calderon I,Blumenfeld Z. Subsequent successful pregnancy and delivery after intracytoplasmic sperm injection in a patient with XY gonadal dysgenesisms.Eur J Obstet Gynecol Reprod Biol. 2000;88:101-2.

11. Selvaraj K, Ganesh V, Selvaraj P. Successful pregnancy in a patient with a 46, XY karyotype. Fertil Steril. 2002;78:419-20.

12. Chen MJ, Yang JH, Mao TL, Ho HN, Yang YS. Successful pregnancy in a gonadectomized woman with 46, XY gonadal dysgenesis and gonadoblastoma. Fertil Steril. 2005;84:217.

13. Ko PC, Peng HH, Soong YK, Chang SD. Triplet pregnancy complicated with one hydatidiform mole and preeclampsia in a $46, \mathrm{XY}$ female with gonadal dysgenesis. Taiwan J Obstet Gynecol. 2007;46:27680.

14. Plante BJ, Fritz MA. A case report of successful pregnancy in a patient with pure $46, \mathrm{XY}$ gonadal dysgenesis. Fertil Steril. 2008;90:2015.e1-2.

15. Siddique H, Daggett P, Artley K. Successful term vaginal delivery in a 46, XY woman. Int J Gynaecol Obstet. 2008;101:298-9.

16. Tulic I, Tulic L, Micic J. Pregnancy in patient with Swyer syndrome. Fertil Steril. 2011;95:1789.e1-2

17. Creatsas G, Deligeoroglou E, Tsimaris P. Successful pregnancy in a Swyer syndrome patient with preexisting hypertension. Fertil Steril. 2011;96:2.e83-5.

18. Mousavi A, Gilani, MM, Goodarzi S. Long-term Disease Free and Successful Pregnancy in a Woman with Gonadal Dysgenesis and Malignant Germ Cell Tumor. Journal of Family and Reproductive Health. 2012;6:91-4. 
19. Canonico M, Oger E, Conard J, Meyer G, Levesque H, Trillot N. Estrogen, Group THRS. Obesity and risk of venous thromboembolism among postmenopausal women: differential impact of hormone therapy by route of estrogen administration. The ESTHER Study. J Thromb Haemost. 2006;4:1259-65.

Cite this article as: Kalra A, Nadkarni PK, Singh PP, Nadkarni AA. Successful pregnancy outcome in a case of Swyer Syndrome with hypertension and morbid obesity. Int J Reprod Contracept Obstet Gynecol 2016;5:2061-4. 